\title{
Access to Debt Finance and Performance of Small and Medium Enterprises
}

\author{
Lwidiko Badi ${ }^{*}$, Esther Ishengoma² \\ ${ }^{1}$ Economics Department, Mwalimu Nyerere Memorial Academy, Dar es Salaam, Tanzania \\ ${ }^{2}$ Department of Finance, University of Dar es Salaam Business School, Dar es Salaam, Tanzania \\ Email: *lwidikobadi2015@gmail.com, i_esther@yahoo.com
}

How to cite this paper: Badi, L., \& Ishengoma, E. (2021). Access to Debt Finance and Performance of Small and Medium Enterprises. Journal of Financial Risk Management, 10, 241-259.

https://doi.org/10.4236/jfrm.2021.103014

Received: June 7, 2021

Accepted: August 7, 2021

Published: August 10, 2021

Copyright (c) 2021 by author(s) and ScientificResearch Publishing Inc.

This work is licensed under the

CreativeCommons Attribution

International

License (CC BY 4.0).

http://creativecommons.org/licenses/by/4.0/

\begin{abstract}
The study investigated the effects of access to debt finance on the performance of SMEs in Tanzania. Data for the study was collected from SMEs which were being served by Private Agricultural Sector Support (PASS) to get credit facilities from formal financial institutions. The study collected data from 115 respondents, out of 152 respondents who were provided questionnaires. The collected data were analyzed quantitatively through Standard Multiple Regression to test the hypothesis that "There is a positive effect of access to debt finance on the performance of SMEs". The results indicate that access to debt finance influences the profitability of SMEs. Also, it was revealed further that the effects were greater for ROA compared to GPM and ROE. This implied that access to debt finance increases the profitability of SMEs relative to total assets. It is, therefore, concluded that access to debt finance is an important ingredient for SMEs' growth and performance.
\end{abstract}

\section{Keywords}

SMEs, Access to Debt Finance and Performance

\section{Introduction}

Access to debt finance is one of the big challenges for SMEs around the globe. (Motta, 2020) contend that lack of access to appropriate financial services is one among many obstacles for SMEs. In Sub-Saharan Africa, the challenge of SMEs' access to debt finance is, to a certain extent, greater than the rest of the world. Studies indicate that more than $25 \%$ of SMEs rate access to debt finance as being one of the big challenges that affects firms' performances (Motta, 2020; Ayyagari, Meghana, \& Maksimovic, 2011; Hallward-Driemeier \& Aterido, 2007). On the other hand, a study of SMEs in UK, indicated that 19\% of SMEs, reported that 
access to debt finance is the main constraint they face (ACCA, 2009).

The challenge of SMEs regarding access to debt finance is brought about by the nature and operations of SMEs. In their operations, SMEs do not maintain and keep records of their business transactions (Musah, 2017), hence, rendering it difficult to compile reliable financial statements that could measure their performance. Furthermore, the lack of assets that can be used as collateral for their loans discourages financial institutions from lending to SMEs, as they consider them to be more risky (Fuad, 2020). These challenges have led financial institutions to reject SMEs' loan applications, for the reasons that they are more risky and not credit-worthy.

In addition to this challenge, studies indicate that access to debt finance is one of the ingredients that activates SMEs to improve financial performance. (Mori 2018) and (ACCA, 2009) stress that access to debt finance is one of the key elements that determine the growth and survival of SMEs in both developing and developed countries. With access to debt finance, SMEs undertake productive investment and contribute highly to economic development, as well as poverty alleviation (Beck, Demirgüç-Kunt, Laeven, \& Maksimovic, 2004). (Hallward-Driemeier \& Aterido, 2007) argued that access to debt finance is among the issues that propel relatively faster growth in SMEs in Africa. In addition, (Aminu \& Shariff, 2015) argued that access to debt finance is a vital tool for the survival and operations of any business. The studies by (Levine, 2005) and (Bigsten et al., 2003) comment that access to debt finance is the main constraint to SMEs in Africa that prevents SMEs from achieving their objectives and also restricts the development of aspirational objectives for the African nations at large.

With limited access to debt finance from financial institutions, SMEs opt to finance their businesses by using their internal finance, that is their own funds, and that of family and friends, money lenders and profits generated from their businesses (Beck et al., 2004). Such financing sources are usually inadequate and others, such as money lenders, are more prone to risk and, hence, this fails to increase SMEs' growth aspirations to achieve their objectives. Therefore, in addition to internal financing, SMEs opt for external financing from financial institutions as it is important for them to excel. Hence, the government of Tanzania has launched policies and programmes to facilitate SMEs with better financial products that are tailored to their needs (Mori, 2018; Olomi et al., 2007).

The government of Tanzania has made a reform to the financial sector and launched a Business Development Services (BDS) program to promote lending to SMEs (URT, 2001, 2003). These initiatives are aimed to ensure that SMEs access debt finance that suits their needs and accelerates their performance, thereby contributing to the nation's economic development and creating employment (Ayyagari, Meghana, \& Maksimovic, 2011). The government and Business Development Services Providers (BDSP) act as the middleman between banks and SMEs, to share risks if SMEs fail to repay the loans advanced. Such facilitation enables SMEs to access debt finance that meets the three dimensions of affordability, favorable timelines and adequacy, which are geared up to improve 
the performance of SMEs.

There is a conviction that access to debt finance meets these three dimensions that trigger the performance of SMEs and leads to higher contributions to economic development and employment creation. (Hallward-Driemeier \& Aterido, 2007) stressed that improved access to debt finance is one area that leads to higher growth across the size spectrum, even though the extent of its benefits for the same level of finance is lower in Africa. However, affordable debt finance enables SMEs which have been neglected by formal financing to get financing at an affordable price, at a convenient time and of an amount adequate to meet their needs (Sukumaran, 2015). In addition, the OECD defines access to debt finance as the promotion of an affordable, timely and adequate range of regulated financial products and services, with a broadening of its use to all segments of society through improved financial awareness and education ( $\mathrm{Pal} \& \mathrm{Pal}$, 2012). (Biswas, 2014) pointed out that affordable, timely and adequate credit access is one of the issues that constrain the performance of SMEs.

Studies point out that SMEs create, on average, $60 \%$ of employment in the manufacturing sector, both in developed and developing economies (Ayyagari, Meghana, \& Maksimovic, 2011). In Tanzania, particularly, SMEs contribute 35\% of GDP and 27\% of employment (URT, 2007). The important aspects of these SMEs' development are access to debt finance, particularly finance that is affordable, timely and adequate from external sources (Le, Venkatesh, \& Nguyen, 2006). This access to debt finance with three elements is envisaged to spur SMEs' performances and enforce high contributions to economic development.

Despite access to debt finance is seen as the main driver to SMEs' performances, studies that have examined the effects of SMEs' financing from external sources have come up with different results. (Modigliani \& Miller, 1959) respectively, reached opposing conclusions, although (Myers \& Majluf, 1984) prioritized the use of debt finance as the best option once the internal sources are exhausted. Following capital structure propositions, a number of studies have been conducted to verify these opposing conclusions.

Other studies, for instance, (Majumdar \& Chhibber, 1999), (Mesquita \& Lara, 2003), (Basit \& Hassan, 2017), (Sibanda, Hove-Sibanda, \& Shava, 2018) examined the effects of debt financing on the performance of firms and found that it has negative effects on firm profitability. However, other studies found that debt financing has a positive correlation with the performance of the firm (Harelimana, 2017; Abor, 2005; Mesquita \& Lara, 2003). Surprisingly studies such as (Mesquita \& Lara, 2003) and (Cuong \& Canh, 2015) concluded that short-term financing and debt financing below fifty percent of equity increases the value of the firm, while long-term financing and debt financing above fifty percent of equity indicates a negative correlation and decreases the value of the firm.

These studies were conducted in different countries which have different economic conditions and contexts. Furthermore, most of the surveyed firms were listed on the stock exchange and their accessibility to financing from formal banks was different from the SMEs considered in this study. Also, the methodology for 
data collection and analysis may differ from the current study. Furthermore, there are few studies in Tanzania that have explored the effects of access to debt finance on the performance of SMEs, through considering the affordability, timeliness and adequacy of debt finance. Therefore, this study examines the effects of access to debt finance by SMEs that meet those three dimensions on the performance, using the profitability ratios GPM, ROA and ROE, and in the context of Tanzania.

\section{Theoretical Background and Literature Review}

Capital structure refers to the combination of all internal and external sources of capital. The known sources include equity share capital, reserves and surplus, preference share capital, debts, debentures, and others, such as long term sources of finance (Okeke, 2019). SMEs have limited sources of finance because according to the nature of their businesses, they can only use owner savings, loans from family and friends, and debts sources, but equity financing is not attractive to them as it is too demanding and compliance costs are high (Gololo, 2017). The limited sources of finance for SMEs compromises their growth aspirations (Afande et al., 2015; Atiase et al., 2018). This leaves SMEs with the option of owner savings, loans from family and friends, as well as debt finance. Owner-managers have to decide the proportions in which they should use their own finance, and debt finance, for the expansion and growth of their businesses.

Capital structure theory, developed by (Modigliani \& Miller, 1959), propounded that the use of internal or external sources of finance has nothing to do with the growth of a business. However, (Nkurunziza, 2005) argued that the slow growth of SMEs has been attributed to by lack of access to financial resources, while the study by (Durand, 1952) stated that SMEs can decrease their cost of capital and, consequently, increase their value, through debt financing. Studies in this context comment that SMEs' financing by debt is important for realizing their growth goals.

SMEs' financing through debt is very rare, especially for startups. Hence, owner-managers have to strive to ensure that the business is in operation before approaching the lenders. Under this scenario, SMEs are said to follow pecking order theory (POT) (Majluf \& Myers, 1984), which dictates the ranked order of financing decisions (Matias \& Serrasqueiro, 2017). Studies, for instance (Agliardi \& Spanjers, 2016) and (Mwarari \& Ngugi, 2013), identified three alternative orders of financing in POT, namely, internal, debt, and equity, financing, respectively. However, SMEs' owner-managers opt to start with internal financing, and if this source is depleted and more funds are required in the business, they will opt for debt financing because is cheaper than equity financing (Proença, Laureano, \& Laureano, 2014). Further, they argued that if SMEs do not generate enough internal funds, short term debt is more preferred than long term debt, because of the flexibility of repayments and interest rates.

In line with capital structure theories, Trade-Off Theory (TOT) is used to 
strike a balance between the merits and demerits associated with the use of debt financing. Initially, (Modigliani \& Miller, 1963) noted that an optimal capital structure could be acquired through a balance between financial distress costs and the tax benefits. This gave rise for the use of debt financing, as it has an effect on the value of the firm, due to interest payments that are tax deductible. It is a revised theory of capital structure that emphasizes that the use of debt is desirable for the firm's growth. Hence, trade off theory predicts that there is a positive correlation between profitability and debt financing.

Capital structure decisions are very important to SMEs' owner-managers, because the decisions tend to eliminate the inefficiencies caused by information asymmetry (Harris \& Raviv, 1991). Therefore, it advised that SMEs should borrow more when internally generated funds are not sufficient to fulfill the investments needs (Shyam-Saunders \& Myers, 1999). Therefore, there is a direct relationship between access to debt finance and the performance of SMEs. Hence, strategies should be designed to enhance SMEs' access to finance that will foster performance.

Capital structure theories have been used in different studies that relate external financing and the performance of firms. It follows that the use of external finance is a driver for improved firms' financial performances. This may be because lenders have marked SMEs as not being creditworthy, due to lack of collateral assets and high risks. The BDSP that provides support is geared to resolve the credit-constrained problem of SMEs. It will be a link between lending institutions and SMEs. In this case, it will provide assurance about the credit disbursed to SMEs and, in the case of default, and then the BDSP will be responsible. (Berger \& Udell, 2006) emphasize that a good relationship between the lending officer of a financial institution, the BDSP and SMEs' management is a key to eliminate the credit constraints on SMEs. Therefore, the theory of capital structure has been applied in this study, in order to show the relationship that exists between access to debt finance and the performance of SMEs.

\section{Access to debt finance}

Access to debt finance is the ready availability of banking services, at affordable costs, in reasonable time, and in adequate amounts to needy people (Rangarajan, 2008). (Claessens, 2006) defined access to debt finance as the availability of a supply of reasonable quality financial services at reasonable costs. However, access to debt finance is a means through which firms get debt finance, in the form of loans, from lending institutions and then promise to repay the loans within given periods of time and at given interest rates (Cooper \& Ejarque, 2003). This form of financing is the one most commonly used by firms, including SMEs, to get funds for investment and to finance new businesses. In this context, access to debt finance involves agreements between lenders and borrowers concerning the fixed interest rates to be paid, the types and sizes of the loans and the repayment periods. Loans with maturity dates of under a year are termed as short term, while those with maturity dates of more than one year are termed as long term (Mahembe, 2011). 
Access to debt finance is in different forms, namely, secured and unsecured. Secured debt is backed by collateral, so that in the case of default it is used to recover the principal loan (Falkena et al., 2001). In the case of an unsecured loan, the lender provides the loan on the grounds of the reputation of the borrower and the strong relations between the borrower and the lender. In such circumstances, usually a short-term loan is preferred to a long-term one, because with long term loans the interest rates are always high (Cole, 2003).

\section{Performance of SMEs}

Performance is a term used to show the effectiveness of something in achieving the intended objective. According to (Brown, 1996), performance must focus on what makes, identifies and communicates the drives of success, support organization learning and provides a basis for assessment and rewards. On the other hand, (Mansfield \& Mitchell, 1996) defines performance as a function of an organization' ability to meet its goals and objectives by exploiting the available resources in an efficient and effective way. According to (Nuhiu, Hoti, \& Bektashi, 2017) profitability has been the most widely used measure of financial performance. The main profitability ratios used in measuring performance includes Gross Profit Margin (GPM), Return On Assets (ROA) and Return On Equity (ROE) along with their variability as measures of risk.

Profitability is the financial measures of performance that measures how well the firms use its assets to generate revenues. There are different ways to measure SMEs' financial performance. Quantitative measures of SMEs performance include profitability measures, cash flow and growth (Singh \& Kumar, 2017). These are used to measure SME's performance because the current operating conditions will influence future performance.

\section{Access of debt finance and SMEs performance}

Access to debt finance is indispensable for the performance of firms, whereas financing that is affordable, timely and adequate is essential for the effective performance of businesses and other enterprises in the world, including SMEs. Such financing enables SMEs and other firms to boost investment and carry out new projects. Studies in this field have pointed out the challenges faced by SMEs in accessing debt finance, but not how the accessed debt finance is spent to accelerate performance (Fatoki \& Smit, 2011; Beck, 2007). It is, therefore, necessary to examine the influence of access to debt finance on the performance of SMEs based on the factors of affordability, timeliness and adequacy.

The principal objective of firms to access debt finance is to acquire productive assets and working capital for spurring productivity and performance. This aims to increase turnover and the profit margin, which enables survival, growth and the creation of more jobs (Githaiga, 2015). Thus, firm financing and firm performance has a close relationship. It is asserted that loans from commercial banks are the major source of financing for emerging SMEs, as retained earnings are often insufficient and unavailable (Robb \& Robinson, 2014).

Empirical studies of the relationship between access to debt finance and performance have revealed conflicting results. For instance, studies by (Margaritis 
\& Psillaki, 2010), (Saeed, Gull, \& Rasheed, 2013), (Cole, Yan, \& Hemley, 2015), indicate that access to debt finance has a positive effect on performance. However, (Majumdar \& Chhibber, 1999), (Goddard et al., 2005), (Muritala, 2012), (Babalola, 2012) and (Githaiga, 2015) pointed out that there is a significant, negative, relationship between access to debt finance and performance. The above mentioned studies were conducted in Pakistan, France, India, Italy, Brazil, Nigeria, Belgium, Kenya and the USA, in different sectors. It ought to be noted that in the mentioned countries the financial markets are developed. The studies under discussion applied regression analysis of debt ratios, for example, those of short-term liabilities to assets, long-term liabilities to assets and total debt to equity against return on assets and return on equity, as a measure of performance. Other studies found that the debt-to-equity ratio had both negative and positive relationships with return on assets and return on equity (Abor, 2005; Githaiga, 2015; Mesquita \& Lara, 2003).

(Campello, 2006) investigated whether debt boosts or hurts firms' performance, and discovered that both results could be obtained. He argued that, to a certain extent, access to debt finance boosts performance, whereas high indebtedness leads to underperformance. The two contradictory results may be related to how the debt was accessed, whether it was affordable and adequate, or whether it was accessed at the appropriate time. Thus, the approach to access to debt finance may have a major impact on performance and should be investigated.

Apart from these studies, only a few of them examined the influence of BDS, access to debt finance and the performance of SMEs. (Mbura \& Bambaganya, 2016) examined the effectiveness of BDS in improving access to debt finance by SMEs and found that those SMEs that were aware of the programme and its usefulness improved their access to debt finance. In this regard, BDS in training, financial linkages and guarantee are important aspects in evaluating access to debt finance and the performance of SMEs.

Access to debt finance is indispensable to the survival and performance of any business enterprise. Limited access to debt finance in Sub-Saharan Africa has been pointed out to constrain the establishment and performance of SMEs (Okpara, 2011). No enterprise, no matter how well managed, can survive without sufficient funds for working capital, fixed assets, employment of a skilled labour force and acquisition of new technologies (Harash, Al-Timimi, \& Alsaadi, 2014). In addition, without sufficient funds SMEs cannot expand to compete in global markets, or even strive to link with large companies (Harash et al., 2014). Although access to debt finance is an important ingredient of the performance of SMEs, it is advisable that access to debt finance and finance use should be differentiated. It could be easy for SMEs to access debt finance, but the same SMEs could be unable to use such finance prudently for various reasons, such as lack of awareness, high costs of access, and a lengthy processing time. (Mahmud \& Tarik, 2019), and (Biswas, 2014) and (Sukumaran, 2015) maintain that access to affordable, timely and adequate debt finance propels performance of firms. On the basis of the blended theoretical and empirical literature, it is, therefore, stated 
that access to debt finance has a positive effect on the performance of SMEs. According to (Watson, 2007), performance is measured in terms of profitability ratios, such as GPM, ROA and ROE. Based on the theoretical and literature review, this research develops a conceptual framework showing the relationship between access to debt finance and the performance of SMEs, illustrated in Figure 1 below.

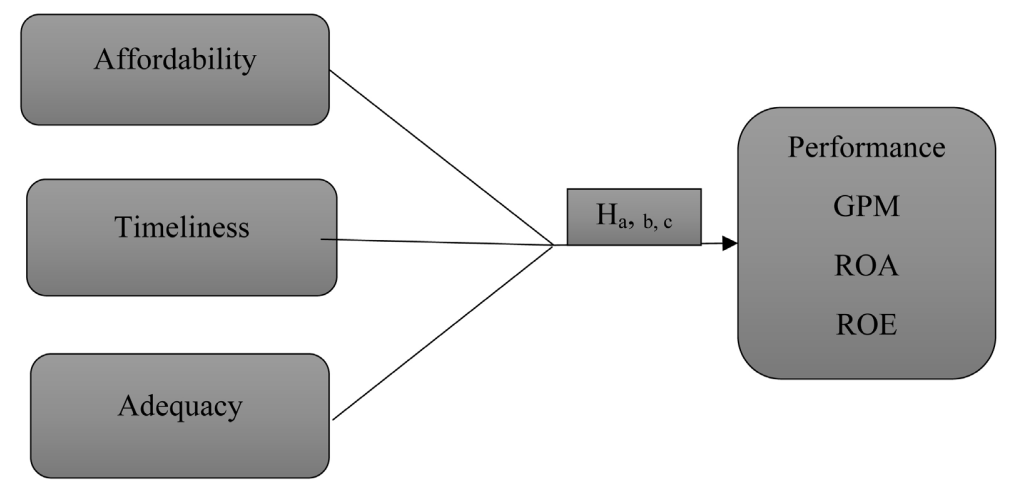

Figure 1. Conceptual framework.

Therefore:

Hypothesis 1: Access to debt finance has a positive effect on SMEs' performance.

This hypothesis is divided into three sub-hypotheses, which are stated as follows:

Hypothesis 1a: Access to debt finance has positive effects on GPM.

Hypothesis 1b: Access to debt finance has positive effects on ROA.

Hypothesis 1c: Access to debt finance has positive effects on ROE.

\section{Research Methodology}

\section{Population, sample size and sampling technique}

This study draws on data from a survey of SMEs served by the Private Agricultural Sector Support (PASS) in Tanzania. From a list of 250 SME clients provided by PASS zonal offices in Coast, Highland and Lake Zone, only 152 SMEs had characteristics required by the researcher. These were SMEs that had been supported by PASS to get credit from formal financial institutions and also these SMEs were keeping accounts records. To ensure the efficiency and effectiveness of data collection exercise, important information about the business owners was collected from PASS in a respective zonal office. Crucial information included the mobile number, email address, and name of key owners, business name and the business location. The sample of 152 SMEs was reasonable according to (Chuan \& Penyelidikan, 2006), using sample size estimation formula of Krejcie and Morgan and also it is above the minimum sample size recommended of 100 (Mundfrom, Shaw, \& Ke, 2005).

\section{Data collection}


Questionnaires were distributed to respective respondents following the sampled SMEs received from PASS. Some were distributed in person by the researcher and respondents were requested to fill them out in the presence of the researcher, as per (Churchill \& Bly, 1999), while others were mailed to the email address collected from PASS. This was proceeded by a call to inform the respondents that a questionnaire was being emailed to him and to request for it to be completed and returned. At the end, out of 152 questionnaires distributed, only 115 were returned completely filled, forming a response rate of 76 percent. However, the list of SMEs provided included some SMEs which had already closed and others had an outstanding loan. These persons were not responding to phone calls, and those who happened to pick up their phone didn't continue to cooperate once we introduced them that we were doing research and that their mobile number had been obtained from PASS.

\section{Study variables}

The study, generally, was concerned with the effects of access to debt finance on the performance of SMEs. Therefore, the critical variables of interest were access to debt finance and performance. Variables considered for the access to debt finance were affordability, timeliness and adequacy, while performance variables were the profitability ratios, such as Gross Profit Margin (GPM), Return On Assets (ROA), and Return On Equity (ROE). Access to debt finance variables were measured using a Likert scale from 1 , strongly disagree, to 5 , strongly agree; these were continuous data, while performance variables were ratios. These variables were similar to those used in other studies (see for example: Otieno \& Kiraka, 2009; Kessy \& Temu, 2010; Vogel \& Adams, 1997).

SMEs are privately owned and, as such, they are under no obligation to provide data about their operations. Hence, the choice of variables for this study took consideration of the willingness of the respondents to share information.

\section{Validity and reliability}

Before running the regression analysis, a validity and reliability test of variables used in the study was performed. Exploratory Factor Analysis (EFA) was used to establish the convergent validity. According with (Schmitt \& Sass, 2011), varimax rotation was performed and variables with high factor loadings were retained, while those variables with low factor loadings were ignored.

The results of the EFA indicated that the sample size was adequate, because the $\mathrm{KMO}$ was 0.651 . According to the rule of thumb, a KMO between 0.6 to 1 indicates that a sample is adequate, while a KMO below 0.6 shows that the sample is inadequate and that remedial action is required (Wahyudi, Sulistiani, \& Muhajat, 2019; Saeed, Tasmin, Mahmood, \& Hafeez, 2021). Also, the total variance explained was $58 \%$, indicating a strong strength of association and that a better prediction can be made using the data obtained (Shirk \& Karver, 2003). The EFA results and the internal consistency results allowed the tests of the hypotheses to be carried out, as these conditions were met. This follow The Cronbatch's alpha for the three items was 0.643 above the minimum of 0.5 that is ac- 
ceptable, indicating strong internal consistency (Hayward \& Homer, 2017; Nunnually, 1978). The results are shown in Table 1 and Table 2, below.

\section{Data analysis}

This study made use of the regression analysis model to represent the relationship between variables. In this study access to debt finance dimensions that are affordability, timeliness and adequacy were linked to performance as the dependent variable. SPSS Version 24 computer programme was applied in data analysis. This programme is helpful because it has ability to take data from almost any type of file and use it to generate tabulated reports, charts, perform descriptive statistics and even perform complex statistical analyses.

The regression model of the form:

$$
Y_{i}=\beta_{0}+\beta_{1} x_{i 1}+\beta_{2} x_{i 2}+\beta_{3} x_{i 3}+\varepsilon \text { for } i=1,2,3, \cdots, n
$$

where:

$Y_{i}$ : Dependent ( $i=\mathrm{GPM}, \mathrm{ROA}$, and ROE);

$X_{1}$ : Latent variables of affordability (AFF1-AFF 5);

$X_{2}$ : Latent variables of timeliness (TM1-TM5);

$X_{3}$ : Latent variables of adequacy (ADEQ1-ADEQ5);

$\beta_{0}$ : Constant for $Y_{i}$;

$\beta_{1}$ : Affordability coefficient;

$\beta_{2}$ : Timeliness coefficient;

$\beta_{3}$ : Adequacy coefficient;

$\varepsilon$ : Error terms as a result of measurement errors of the relationship between independent and dependent variables.

Based on the above breakdown of the variables, the results of regression analysis are summarized in Table 1.

\section{Results and Discussion}

\section{Sample characteristics}

Findings are presented in the context of sex, age, marital status, education and category of respondent. In this study most of the respondents participated were males who constituted (77.4\%) of the sample and (50\%) of them were on the age

Table 1. KMO and Bartlett's test.

\begin{tabular}{ccc}
\hline \multicolumn{2}{c}{ Kaiser-Meyer-Olkin measure of sampling adequacy } & 0.651 \\
\hline & Approx. Chi-Square & 43.530 \\
Bartlett's test of sphericity & Df & 3 \\
& Sig. & 0.000 \\
\hline
\end{tabular}

Table 2. Reliability statistics.

\begin{tabular}{ccc}
\hline Cronbach's Alpha & Cronbach's Alpha based on standardized items & N of Items \\
\hline 0.643 & 0.644 & 3 \\
\hline
\end{tabular}


group between 41 to 50 . About the marital status almost (89\%) were married while $(48.7 \%)$ of these respondents had reached a primary level of education. The respondents were categorized into owner managers, managers and others. However, in the study owner managers constituted $(66.7 \%)$ of the sample. Table 3 displays the results.

\section{Correlation analysis}

Prior to the test of the relationship between access to debt finance and performance using the regression model, a correlation analysis was performed to test the strength of the independent and dependent variables. The correlation matrix results indicated that return on assets (ROA) was statistically significant $\left(\mathrm{r}=0.195^{\star}, p<0.05\right)$, while other variables of performance were positive, but

Table 3. Demographic characteristics of respondents.

\begin{tabular}{|c|c|c|c|c|}
\hline S/No. & Details & Category & Frequency & Percent \\
\hline \multirow{3}{*}{1} & \multirow{3}{*}{ Sex } & Male & 89 & 77.4 \\
\hline & & Female & 26 & 22.6 \\
\hline & & Total & 115 & 100.0 \\
\hline \multirow{6}{*}{2} & \multirow{6}{*}{ Age } & 18 below & 3 & 2.6 \\
\hline & & $18-30$ & 6 & 5.2 \\
\hline & & $31-40$ & 27 & 23.5 \\
\hline & & $41-50$ & 50 & 43.5 \\
\hline & & 50 and above & 29 & 25.2 \\
\hline & & Total & 115 & 100.0 \\
\hline \multirow{4}{*}{3} & \multirow{4}{*}{ Marital Status } & Single & 9 & 7.8 \\
\hline & & Married & 103 & 89.6 \\
\hline & & Others & 3 & 2.6 \\
\hline & & Total & 115 & 100 \\
\hline \multirow{8}{*}{4} & \multirow{8}{*}{ Education Level } & Masters and Above & 24 & 20.9 \\
\hline & & Degree & 11 & 9.6 \\
\hline & & Diploma & 7 & 6.1 \\
\hline & & Certificate & 2 & 1.7 \\
\hline & & "A" Level Education & 2 & 1.7 \\
\hline & & "O" Level Education & 13 & 11.3 \\
\hline & & Primary School & 56 & 48.7 \\
\hline & & Total & 115 & 100 \\
\hline \multirow{4}{*}{6} & \multirow{4}{*}{$\begin{array}{l}\text { Category of } \\
\text { respondents }\end{array}$} & Owner Managers & 76 & 66.1 \\
\hline & & Managers/operator & 32 & 27.8 \\
\hline & & Others (Secretary) & 7 & 6.1 \\
\hline & & Total & 115 & 100 \\
\hline
\end{tabular}

Source: (Field Data, 2018). 
statistically insignificant. This implied that these variables of access to debt finance and performance were correlated but had no effect, because a change in predictor variables did not have association with changes in the response variables. Table 4 below shows the results.

\section{Multivariate analysis}

A standard multiple linear regression was performed to test the relationship between access to debt finance and performance of SMEs. Dependent variables were Gross Profit Margin (GPM), Return On Assets (ROA) and Return On Equity (ROE) while independent variable access to debt finance was in three dimension affordability, timeliness and adequacy. Hence, the regression model was run three times using GPM, ROA and ROE as the dependent variables against access to finance dimensions. The results of multivariate analysis are discussed below and Table 5 below displays the results.

\section{Access to debt finance and Gross Profit Margin}

Data for access to debt finance and Gross Profit Margin (GPM) were regressed. The regression followed the sub-hypothesis $\mathrm{H}_{\mathrm{a}}$ which stated that access to debt finance has a positive effect on SMEs' Gross Profit Margins (GPM). Upon the regression, it was confirmed that the regression model fitted the data, because the ratio of variation between the sample means and the variation within the sample means was low and statistically insignificant at $\left(p=0.457^{\mathrm{b}}\right)$, and the $\mathrm{F}$ value was (0.874). Moreover, residual errors were not correlated, as the Durbin-Watson test indicated a value of (2.069), implying that residual errors could neither cause underestimation, nor overestimation, of the significance values.

Furthermore, the regression results showed that R-squared is (0.023), indicating that $2.3 \%$ of the GPM variation change is explained by log affordability, log timeliness and log adequacy of debt finance. This implies that the $2.3 \%$ change in GPM is caused by the predictor variables when other factors remain constant. Although the R-squared is low, the trend indicates that the predictor variable still provides information about the response variable, even though data points

Table 4. Correlation matrix of access to debt finance and performance variables.

\begin{tabular}{|c|c|c|c|c|}
\hline & & GPM & ROA & ROE \\
\hline & Pearson's correlation & 0.123 & $0.195^{\star}$ & 0.159 \\
\hline \multirow[t]{3}{*}{ Log affordability } & Sig. (2-tailed) & 0.189 & 0.037 & 0.091 \\
\hline & $\mathrm{N}$ & 115 & 115 & 115 \\
\hline & Pearson's correlation & 0.124 & 0.156 & 0.032 \\
\hline \multirow[t]{3}{*}{ Log timeliness } & Sig. (2-tailed) & 0.185 & 0.096 & 0.734 \\
\hline & $\mathrm{N}$ & 115 & 115 & 115 \\
\hline & Pearson's correlation & 0.090 & 0.152 & 0.007 \\
\hline \multirow[t]{2}{*}{ Log adequacy } & Sig. (2-tailed) & 0.339 & 0.105 & 0.940 \\
\hline & $\mathrm{N}$ & 115 & 115 & 115 \\
\hline
\end{tabular}

${ }^{*}$ Correlation is significant at the 0.05 level (2-tailed). 
Table 5. Access to debt finance on performance of SMEs (t-statistics in brackets).

\begin{tabular}{cccc}
\hline Variables & $\mathbf{1}$ & $\mathbf{2}$ & $\mathbf{3}$ \\
\cline { 2 - 4 } & GPM & ROA & ROE \\
\hline Constant & 0.074 & -0.072 & 0.081 \\
Log affordability & 0.084 & 0.143 & 0.181 \\
Log timeliness & $(0.813)$ & $(1.401)$ & $(1.754)$ \\
& 0.084 & 0.076 & $(0.011)$ \\
Log adequacy & $(0.787)$ & $(0.725)$ & $(0.104)$ \\
R & 0.025 & 0.069 & $(0.053$ \\
R-Square & $(0.236)$ & $(0.662)$ & $(0.499)$ \\
Adjusted R-square & $0.152^{\mathrm{a}}$ & $0.224^{\mathrm{a}}$ & $0.167^{\mathrm{a}}$ \\
F-Value & 0.023 & 0.05 & 0.028 \\
DF & $(0.003)$ & 0.025 & 0.002 \\
Sig. F change & 0.874 & 1.962 & 1.066 \\
Durbin Watson & 3 & 3 & 3 \\
\hline & 0.457 & 0.124 & 0.366 \\
& 2.069 & 1.805 & 1.861 \\
\hline & & & \\
\hline & 3 & 3 & \\
\hline
\end{tabular}

fall further from the regression line. This is confirmed by the statement by (Wasserman, 2013), who contends that in social or behavioral science all relevant predictors are not expected to be included to explain an outcome variable.

In addition to the detailed results about the regression model, the predictive power of the independent variables indicates the relative importance of each variable. Log affordability was ranked first in predicting GPM, because it had a high positive beta value, but was statistically insignificant (Beta $=0.084, t=$ 0.813 , sig. $=0.418$ ), followed by $\log$ timeliness with (Beta $=0.084, t=0.787$, sig. $=0.433)$, whereas log adequacy had a positive beta and was statistically insignificant (Beta $=0.023, t=-0.236$, sig. $=0.813$ ). All the variables had low beta values, but were not significant, as the $\mathrm{p}$ value was greater than 0.05 . This means that the data provided evidence to reject the null hypothesis and to inform that $\log$ timeliness and log affordability contributed to the SMEs' performances, while log adequacy made a negative contribution to SMEs' performances. Table 5 presents the results of the regression model of access to debt finance against GPM.

\section{Access to debt finance and Return on Assets}

The test was conducted to test the relationship between access to debt finance and Return On Assets (ROA). The test was done following the sub-hypothesis $\mathrm{H}_{\mathrm{b}}$, which stated that access to debt finance has a positive effect on Return On Assets (ROA). The results indicated that the regression model fit index matched with the model, with $(p=0.124)$ and $\mathrm{F}$ value (1.962). The residual error index indicated a value of (1.805), implying that the nonexistence of autocorrelation in 
the residuals. These measurement values indicated that the regression model fitted the data and eliminated the issue of either underestimation, or overestimation, of the significant values.

The R-squared results on the regression model had a coefficient of (0.05), implying that $5.0 \%$ of the variance change in SMEs ROA was caused by the change in $\log$ affordability, $\log$ timeliness and log adequacy of debt finance, if other variables were kept constant. However, the examination of access to debt finance variables separately indicated that $\log$ affordability had a positive and statistically insignificant predictive power, with (Beta $=0.143, t=1.401, p=0.164$ ), followed by $\log$ timeliness, with (Beta $=0.076, t=0.725, p=0.470$ ), and log adequacy had (Beta $=0.069, t=0.662, p=0.509$ ). The positive sign in the results indicates that the change in each variable increased the variation change in ROA. However, the results were rather different from the model that predicted GPM, whereby only two variables had positive coefficients, while the rest had negative coefficients with insignificant $p$ values. Table 5 presents the results of multiple regression analysis.

\section{Access to debt finance and Return on Equity}

Furthermore a test of sub-hypothesis $\mathrm{H}_{\mathrm{c}}$ for the relationship between access to debt finance and Return On Equity (ROE) indicated that the model fitted the data at the significant level $(p=0.366)$ and the F-value of $(1.066)$. The Durbin -Watson test of autocorrelation had a value of (1.861), implying that there was no autocorrelation of residuals as per Durbin-Watson (DW) 1995 bound test. However, the regression coefficient R-squared was (0.028), implying that $2.8 \%$ variance change in ROE was explained by log affordability, log timeliness and log adequacy. Also, access to debt finance variables were ranked according to their predictive power, whereby log affordability access to debt finance was ranked first owing to its positive and significant value at (Beta $=0.181, t=1.754$ and $p=0.082$ ), followed by log timeliness, which had a negative coefficient and was statistically insignificant with (Beta $=-0.11, t=-0.104, p=0.917) . \log$ adequacy was ranked third and the last, due to its negative coefficient and insignificant value at (Beta $=-0.053, t=-0.499, p=0.619$ ). Table 5 displays the results of the regression model.

\section{Conclusion}

This study examined the effects of access to debt finance on the performance of SMEs in Tanzania. Access to debt finance variables considered in the study was affordability, timeliness and adequacy, while the performance variables undertaken were the profitability ratios (GPM, ROA and ROE). The findings revealed that the effects of access to debt finance on the performance of SMEs exist, although it is weak. The findings revealed further that the effects of access to debt finance are high on ROA compared to GPM and ROE. This is because, as the SMEs gets debt finance and use it in business, the profitability of SMEs increases relative to total assets. The study concludes that access to debt finance is an im- 
portant ingredient in the SMEs' performance, as without it SMEs' performance is weak and, most likely, the businesses may take long time to realize their performance potential.

\section{Recommendation}

According to the findings of the study, SMEs feel that they are neglected by the formal financial institutions, hence making it difficult to access debt finance. Therefore deliberate efforts are needed to ensure that financing is available to SMEs at affordable cost, appropriate time and adequate. With access to debt finance with three characteristics, SMEs will be able to improve performance and therefore create more employments and increase the nation's income. Hence, the governments should deliberately provide guidelines to financial institutions in providing debt finance to SMEs. Moreover, governments should always monitor the financial access level of SMEs and set the rules as well as the regulations to improve SMEs.

\section{Conflicts of Interest}

The authors declare no conflicts of interest regarding the publication of this paper.

\section{References}

Abor, J. (2005). The Effect of Capital Structure on Profitability: An Empirical Analysis of Listed Firms in Ghana. The Journal of Risk Finance, 6, 438-445. https://doi.org/10.1108/15265940510633505

ACCA (2009). Access to Finance for the Small and Medium Sized Enterprise Sector Evidence and Conclusions Access to Finance for the Small and Medium Sized Enterprise Sector Evidence and Conclusions. ACCA.

Afande, F. O., Maina, W. N., \& Maina, M. P. (2015). Youth Engagement in Agriculture in Kenya: Challenges and Prospects. Journal of Culture, Society and Development, 7, 4-19.

Agliardi, E., Agliardi, R., \& Spanjers, W. (2016). Corporate Financing Decisions under Ambiguity: Pecking Order and Liquidity Policy Implications. Journal of Business Research, 69, 6012-6020. https://doi.org/10.1016/j.jbusres.2016.05.016

Aminu, I. M., \& Shariff, M. N. M. (2015). Influence of Strategic Orientation on SMEs Access to Finance in Nigeria. Asian Social Science, 11, 298. https://doi.org/10.5539/ass.v11n4p298

Atiase, V. Y., Mahmood, S., Wang, Y., \& Botchie, D. (2018). Developing Entrepreneurship in Africa: Investigating Critical Resource Challenges. Journal of Small Business and Enterprise Development, 5, 644-666. https://doi.org/10.1108/JSBED-03-2017-0084

Ayyagari, Meghana, A. D.-K., \& Maksimovic, V. (2011). Small vs. Young Firms across the World Contribution to Employment, Job Creation, and Growth. Policy Research Working Papers. https://doi.org/10.1596/1813-9450-5631

Babalola, Y. A. (2012). The Determinants of Bank's Profitability in Nigeria. Journal of Money, Investment and Banking, 24, 6-16.

Basit, A., \& Hassan, Z. (2017). Impact of Capital Structure on Firms Performance: A 
Study on Karachi Stock Exchange (KSE) Listed Firms in Pakistan. International Journal of Management, Accounting and Economics, 4, 118-135.

Beck, T. (2007). Financing Constraints of SMEs in Developing Countries: Evidence, Determinants and Solutions. In KDI 36th Anniversary International Conference (pp. 26-27).

Beck, T., Demirgüç-Kunt, A., Laeven, L., \& Maksimovic, V. (2004). The Determinants of Financing Obstacles. https://doi.org/10.1596/1813-9450-3204

Berger, A., \& Udell, G., (2006). A More Complete Conceptual Framework for SME Finance. Journal of Banking \& Finance, 30, 2945-2966. https://doi.org/10.1016/j.jbankfin.2006.05.008

Bigsten, A., Collier, P., Dercon, S., Fafchamps, M., Gauthier, B., Gunning, J. W., \& Zeufack, A. (2003). Credit Constraints in Manufacturing Enterprises in Africa. Journal of African Economies, 12, 104-125. https://doi.org/10.1093/jae/12.1.104

Biswas, A. (2014). Financing Constraints for MSME Sector. International Journal of Interdisciplinary and Multidisciplinary Studies (IJIMS), 1, 60-68.

Brown, M. G. (1996). Keeping Score: Using the Right Metrics to Drive World-Class Performance. Quality Resources.

Campello, M. (2006). Debt Financing: Does It Boost or Hurt Firm Performance in Product Markets? Journal of Financial Economics, 82, 135-172. https://doi.org/10.1016/j.jfineco.2005.04.001

Chuan, C. L., \& Penyelidikan, J. (2006). Sample Size Estimation Using Krejcie and Morgan and Cohen Statistical Power Analysis: A Comparison. Jurnal Penyelidikan IPBL, 7, 78-86.

Churchill, E. F., \& Bly, S. (1999). Virtual Environments at Work: Ongoing Use of MUDs in the Workplace. ACM SIGSOFT Software Engineering Notes, 24, 99-108.

https://doi.org/10.1145/295665.295677

Claessens, S. (2006). Access to Financial Services: A Review of the Issues and Public Policy Objectives. The World Bank Research Observer, 21, 207-240. https://doi.org/10.1093/wbro/lkl004

Cole, C., Yan, Y., \& Hemley, D. (2015). Does Capital Structure Impact Firm Performance: An Empirical Study of Three US Sectors. Journal of Accounting and Finance, 15, 57.

Cole, R. (2003). How Did the Financial Crisis Affect Small Business Lending in the US? Journal of Financial Research, 43, 767-820.

Cooper, R., \& Ejarque, J. (2003). Financial Friction and Investment: Requiem in Q Review of Economic Dynamics. Review of Economic Dynamics, 6, 710-728. https://doi.org/10.1016/j.red.2003.08.001

Cuong, N. T. and Canh, N. (2015). The Effect of Capital Structure on Firm Value for Vietnam's Seafood Processing Enterprises. International Research Journal of Finance and Economics. http://www.Internationalresearchjournaloffinanceandeconomics.com

Durand, D. (1952). Costs of Debt and Equity Funds for Business: Trends and Problems of Measurement. In Universities-National Bureau (Ed.), Conference on Research in Business Finance (pp. 215-262). National Beaureau of Economic Research.

Falkena, H., Abedian, I., von Blottnitz, M., Coovadia, C., Davel, G., Madungandaba, J., Masilela, E., \& Rees, S. (2001). SMEs Access to Finance in South Africa-A Supply Side Regulatory Review. Policy Board for Financial Services and Regulation.

Fatoki, O. O., \& Smit, A. V. (2011). Constraints to Credit Access by New SMEs in South Africa: A Supply Side Analysis. The African Journal of Business and Management, 5, 
1413-1425.

Fuad, M. (2020). The Role of Relationship Lending in SMEs Funding. In ICBAE 2020: Proceedings of the 2nd International Conference of Business, Accounting and Economics, ICBAE 2020 (333 p.). European Alliance for Innovation.

https://doi.org/10.4108/eai.5-8-2020.2301201

Githaiga, J. W. (2015). Effects of Credit Risk Management on the Financial Performance of Commercial Banks in Kenya. Doctoral Dissertation, University of Nairobi.

Goddard, J., Tavakoli, M., \& Wilson, J. O. (2005). Determinants of Profitability in European Manufacturing and Services: Evidence from a Dynamic Panel Model. Applied Financial Economics, 15, 1269-1282. https://doi.org/10.1080/09603100500387139

Gololo, I. A. (2017). An Evaluation of the Role of Commercial Banks in Financing Small and Medium Scale Enterprises (SMEs): Evidence from Nigeria. Indian Journal of Finance and Banking, 1, 16-32. https://doi.org/10.46281/ijfb.v1i1.82

Hallward-Driemeier, M., \& Aterido, R. (2007). Impact of Access to Finance, Corruption and Infrastructure on Employment Growth: Putting Africa in a Global Context. The World Bank.

Harash, E., Al-Timimi, S., \& Alsaadi, J. (2014). Effects of Financing on Performance of Small and Medium Enterprises (SMEs). International Journal of management, 2, 1-9.

Harelimana, J. B. (2017). Effect of Debt Financing on Business Performance: A Comparative Study between I \& M Bank and Bank of Kigali, Rwanda, Global Journal of Management and Business, 17.

Harris, M., \& Raviv, A. (1991). The Theory of Capital Structure. The Journal of Finance, 46, 297-355. https://doi.org/10.1111/j.1540-6261.1991.tb03753.x

Hayward, E. O., \& Homer, B. D. (2017). Reliability and Validity of Advanced Theory-of-Mind Measures in Middle Childhood and Adolescence. British Journal of Developmental Psychology, 35, 454-462. https://doi.org/10.1111/bjdp.12186

Kessy, S., \& Temu, K. (2010). The Impact of Training on Performance of Micro and Small Enterprises served by Microfinance Institutions in Tanzania. Research Journal of Business Management, 4, 103-111.

Le, N. T. B., Venkatesh, S., \& Nguyen, T. V. (2006). Getting Bank Financing: A Study of Vietnamese Private Firms. Asia Pacific Journal of Management, 23, 209-227. https://doi.org/10.1007/s10490-006-7167-8

Levine, R. (2005). Finance and Growth: Theory and Evidence. Handbook of Economic Growth, 1, 865-934. https://doi.org/10.1016/S1574-0684(05)01012-9

Mahembe, E. (2011). Literature Review on Small and Medium Enterprises' Access to Finance. National Credit Regulator

Mahmud, S., \& Tarik, A. K. İ. N. (2019). SMEs' Access to Finance and Choice of Capital Structure in Turkey. Ege Akademik Bakış Dergisi, 19, 277-291.

https://doi.org/10.21121/eab.521579

Majluf, N. S., \& Myers, S. (1984). Corporate Financing and Investment Decisions When Firms Have Information That Investors Do Not Have. Journal of Financial Economics, 13, 187-221. https://doi.org/10.1016/0304-405X(84)90023-0

Majumdar, S. K., \& Chhibber, P. (1999). Capital Structure and Performance: Evidence from a Transition Economy on an Aspect of Corporate Governance. Public Choice,98, 287-305. https://doi.org/10.1023/A:1018355127454

Mansfield, B., \& Mitchell, L. (1996). Towards a Competent Workforce. Gower Publishing, Ltd.

Margaritis, D., \& Psillaki, M. (2010). Capital Structure, Equity Ownership and Firm Performance. Journal of banking \& finance, 34, 621-632. 
https://doi.org/10.1016/j.jbankfin.2009.08.023

Matias, F., \& Serrasqueiro, Z. (2017). Are There Reliable Determinant Factors of Capital Structure Decisions? Empirical Study of SMEs in Different Regions of Portugal. Research in International Business and Finance, 40, 19-33. https://doi.org/10.1016/j.ribaf.2016.09.014

Mbura, O. K., \& Bambaganya, M. W. (2016). Success and Usefulness of Business Development Services in Tanzania's SMEs Market. Business Management Review, 18.

Mesquita, J. M. C., \& Lara, J. E. (2003). Capital Structure and Profitability: The Brazilian Case (1-14).

Modigliani, F., \& Miller, M. H. (1959). American Economic Association the Cost of Capital, Corporation Finance, and the Theory of Investment. The American Economic Review, 49, 655-669.

Modigliani, F., \& Miller, M. H. (1959). The Cost of Capital, Corporation Finance, and the Theory of Investment: Reply. The American Economic Review, 49, 655-669.

Modigliani, F., \& Miller, M. H. (1963). Corporate Income Taxes and the Cost of Capital: A Correction. The American economic review, 53, 433-443.

Mori, N. G. (2018). Access to Finance for Smes in Tanzania.

Motta, V. (2020). Lack of Access to External Finance and SME Labor Productivity: Does Project Quality Matter? Small Business Economics, 54, 119-134. https://doi.org/10.1007/s11187-018-0082-9

Mundfrom, D. J., Shaw, D. G., \& Ke, T. L. (2005). Minimum Sample Size Recommendations for Conducting Factor Analyses. International Journal of Testing, 5, 159-168. https://doi.org/10.1207/s15327574ijt0502 4

Muritala, T. A., Awolaja, A. M., \& Bako, Y. A. (2012). Small and Medium Enterprises and Economic Growth in Nigeria. Acta Universitatis Danubius: Oeconomica, 8.

Musah, A. (2017). Benefits and Challenges of Bookkeeping and Accounting Practices of SMEs and Its Effect on Growth and Performance in Ghana. Journal of Accounting, Business and Management (JABM), 24, 16-36.

Mwarari, M. \& Ngugi, P. (2013). Factors Influencing Listing of Kenyan SMEs in the Securities Market for Capital Raising Opportunities. European Journal of Management Sciences and Economics, 1, 99-115.

Nkurunziza, J. D. (2005). The Effect of Credit on Growth and Convergence of Firms in Kenyan Manufacturing.

Nuhiu, A., Hoti, A., \& Bektashi, M. (2017). Determinants of Commercial Banks Profitability through Analysis of Financial Performance Indicators: Evidence from Kosovo. Business: Theory and Practice, 18, 160-170. https://doi.org/10.3846/btp.2017.017

Nunnally, J.C. (1978). Psychometric Theory(2nd ed.). McGraw-Hill Book Company.

Okeke, M. (2019). Capital Structure and Firm Value in Nigeria (Evidence from Selected Quoted Firms). Journal on Banking Financial Services \& Insurance Research, 9, 26 p.

Okpara, J. O. (2011). Factors Constraining the Growth and Survival of SMEs in Nigeria: Implications for Poverty Alleviation. Management Research Review. https://doi.org/10.1108/01409171111102786

Olomi, D., Chijoriga, M., \& Mori, N. (2007). Mapping of Obstacles for Establishing and Expanding Business in Tanzania. Dar es Salaam, University of Dar es Salaam.

Otieno, H., Donath, O., \& Kiraka, K. (2009). Building Sustainable Business Development Services: Empiridence from Kenya.

Pal, R., \& Pal, R. (2012). Income Related Inequality in Financial Inclusion and Role of Banks: Evidence on Financial Exclusion in India Income Related Inequality in Finan- 
cial Inclusion and Role of Banks: Evidence on Financial Exclusion in India.

Proença, P., Laureano, R. M., \& Laureano, L. M. (2014). Determinants of Capital Structure and the 2008 Financial Crisis: Evidence from Portuguese SMEs. Procedia-Social and Behavioral Sciences, 150, 182-191. https://doi.org/10.1016/j.sbspro.2014.09.027

Rangarajan, C. (2008). Report of the Committee on Financial Inclusion. Ministry of Finance, Government of India.

Robb, A. M., \& Robinson, D. T. (2014). The Capital Structure Decisions of New Firms. The Review of Financial Studies, 27, 153-179. https://doi.org/10.1093/rfs/hhs072

Saeed, B., Tasmin, R., Mahmood, A., \& Hafeez, A. (2021). Development of a Multi-Item Operational Excellence scale: Exploratory and Confirmatory Factor Analysis. The TQM Journal. https://doi.org/10.1108/TQM-10-2020-0227

Saeed, M. M., Gull, A. A., \& Rasheed, M. Y. (2013). Impact of Capital Structure on Banking Performance: A Case Study of Pakistan. Interdisciplinary Journal of Contemporary Research in Business, 4, 393-403.

Schmitt, T. A., \& Sass, D. A. (2011). Rotation Criteria and Hypothesis Testing for Exploratory Factor Analysis: Implications for Factor Pattern Loadings and Interfactor Correlations. Educational and Psychological Measurement, 71, 95-113. https://doi.org/10.1177/0013164410387348

Shirk, S. R., \& Karver, M. (2003). Prediction of Treatment Outcome from Relationship Variables in Child and Adolescent Therapy: A Meta-Analytic Review. Journal of Consulting and Clinical Psychology, 71, 452-464. https://doi.org/10.1037/0022-006X.71.3.452

Shyam-Saunders, L., \& Myers, S. C. (1999) Testing Static Tradeoff against Pecking Order Models of Capital Structure. Journal of Financial Economics, 51, 219-244.

Sibanda, K., Hove-Sibanda, P., \& Shava, H. (2018). The Impact of SME Access to Finance and Performance on Exporting Behaviour at Firm Level: A Case of Furniture Manufacturing SMEs in Zimbabwe. Acta Commercii, 18, Article ID: a554.

https://doi.org/10.4102/ac.v18i1.554

Singh, H. P., \& Kumar, S. (2017). Working Capital Requirements of Manufacturing SMEs: Evidence from Emerging Economy. Review of International Business and Strategy, 27. https://doi.org/10.1108/RIBS-03-2017-0027

Sukumaran, K. (2015). Financial Access: Inclusion and Literacy. Annual Research Journal of Symbiosis Centre for Management Studies, 3, 188-207.

United Republic of Tanzania (URT) (2001). National Microfinance Policy.

United Republic of Tanzania (URT) (2003). Small and Medium Enterprises (SME) Development Policy. Government Printer.

United Republic of Tanzania (URT) (2007). Household Budget Survey (HBS) 2007. Dar es Salaam.

Vogel, R. C., \& Adams, D. W. (1997). The Benefits and Costs of Loan Guarantee Programs. The Financier, 4, 22-29.

Wahyudi, D., Sulistiani, E., \& Muhajat, M. H. (2019). The Impact of Farmer's Attitude and Perceived Quality to Farmer's Satisfaction and its Effect on Brand Loyalty. Journal of Research in Business, Economics, and Education, 1.

Wasserman, L. (2013). All of Statistics: A Concise Course in Statistical Inference. Springer Science \& Business Media.

Watson, J. (2007). Modeling the Relationship between Networking and Firm Performance. Journal of Business Venturing, 22, 852-874.

https://doi.org/10.1016/j.jbusvent.2006.08.001 